\title{
Interpretation of International Law by National Judges: Opportunities and Challenges. The Case of International Investment Law in Latin America
}

\author{
Marcelo Lozada Gómez* \\ Paola Acosta Alvarado**
}

DOI: $10.21827 / 5 b 51 d 54 f 19 d a 9$

\section{Keywords \\ DOMESTIC JUDGES; NATIONAL AND INTERNATIONAL LAW; LATIN AMERICA}

\begin{abstract}
The role of national judges in international law is still an undecided subject matter. Most scholars consider the decisions from national judges merely as acts of States, denying the possibility that those judgments constitute an autonomous source of international law. This position is grounded in the idea that national judges do not regularly employ sources of international law, and therefore, their opinion about them is not quite important. Nevertheless, recent phenomena have highlighted and triggered the intervention of national judges regarding the interpretation and enforcement of international law. The growing scope of international rules, which now regulate intra-states issues, as well as the fragmentation of international law, and the internationalisation of national orders, inter alia, have demanded domestic courts' intervention in order to face these changes and avoid undesirable consequences. In this context, this article aims to: 1. bring an outlook on the evolution of the role assigned to national judges; 2 . explore the phenomena that triggered their intervention; 3 . analyse the outcomes of this increasing participation, namely how national judges change the usual dynamics of interpretation and evolution of international law; 4. apply these ideas to explain the intervention of national judges in Latin America regarding the enforcement of foreign investment law; and 5. conclude with some remarks about the future of this relationship between national and international law as well as the importance of a better understanding of the role of national judges.
\end{abstract}

\section{Introduction}

The role of interpretation, and therefore the development of international law as we know it, has always been attributed to supranational or international actors or bodies, particularly those endowed with judicial or quasi-judicial functions. ${ }^{1}$ However, nowadays international

* Lecturer of Constitutional Law at Universidad Externado de Colombia.

** Lecturer at Universidad Externado de Colombia, President of Colombian Academy of International Law; Editor in Chief Revista Derecho del Estado; Director of the Interest Groups' LASIL; PhD \& DAE in International Law, LLM in Public Law.

1 Advisory Committee on Issues of Public International Law, REPORT: Advisory report on subsequent agreements and subsequent practice in relation to the interpretation of treaties, Advisory Report No 30, November 
officers or institutions are not the only actors involved in the application, interpretation, and development of international norms. National actors play an increasingly important role in this regard.

The proliferation of judicial or quasi-judicial actors during the twentieth century was meant to support a whole paradigm of international law, where the role of States yielded in favour of an international rule of law. However, this phenomenon entailed certain processes, which pushed other actors to participate in the interpretation and development of international law - the national judges. Many international legal academics such as André Nollkaemper and August Reinisch have examined this endeavour of national actors, trying to demonstrate how these domestic judges could shift the mentioned paradigm. ${ }^{2}$

Considering the aforementioned processes, this article aims to analyse the important role of national judges in interpreting and developing international law, as well as the challenges this new role represents both to national and international law. To do so, first, the context in which this alleged shift has happened will briefly be described. Second, instances when national judges consider international law will be scrutinised. Third, the focus will be on how this proposed shift, namely the intervention of domestic judges, affects international law, especially regarding its interpretation and evolution. Finally, this paper concludes with an overview of this growing dynamic, and the application of these ideas, in the context of international investment law in Latin-American. To conclude, some reflections on the consequences this phenomenon entails, the advantages and challenges it poses, are offered.

\section{Breaking off the International Monopoly on International Law}

Traditionally it has been understood that the interpretation and application of international law rests exclusively with the subjects of international law, states and international institutions. ${ }^{3}$ Under the idea of international law as the law of (and between) sovereign States ${ }^{4}$ there was no point in considering the role that national judges could play in the development of international law. ${ }^{5}$

2017, 13. See also Gourgourinis, A, "The Distinction between Interpretation and Application of Norms in International Adjudication" 2(1) Journal of International Dispute Settlement (2011) 31, 40.

2 See among other works from these scholars: Nollkaemper, A, "National Courts and the International Rule of Law" (Oxford University Press, 2011); Reinisch, A, "Challenging Acts of International Organizations Before National Courts" (Oxford University Press, Oxford, 2011). Finally, see the project Oxford Reports on International Law in Domestic Courts, 2018 at <opil.ouplaw.com/page/ILDC/oxford-reports-oninternational-law-in-domestic-courts> (Accessed on 22 May 2018).

3 In the aftermath of World War II, States accepted an array of varied obligations and delegated some decision-making powers to international agencies. In this sense, "the authority to implement, interpret and apply those rules, and to create further rules and/or settle disputes arising out of their implementation, is often delegated". Romano, CPR, "A Taxonomy of International Rule of Law Institutions" 2 Journal of International Dispute Settlement (2011) 241, 251.

4 Van Alstine also agrees that the main reason to disregard national judges is the inter-state nature of international law, because, "international law generally does not compel a State either to submit to suit in the domestic courts of another or to permit suit against itself on its own". See Van Alstine, MP, "The Role of Domestic Courts in Treaty Enforcement. Summary and Conclusions" in Sloss, D, ed, The Role of Domestic Courts in Treaty Enforcement: A Comparative Study (Cambridge University Press, Cambridge, 2009), 556.

5 As noted by Tzanakopoulos and Tams, back in 1935 some argued that, "questions of international law arise comparatively rarely, and often only incidentally, in the work of municipal courts". Brierly, JL, "International Law in England" 51 Law Quarterly Review (1935) 24, 25, cited by Tzanakopoulos, A, and 
However, the reality that fuelled this idea has changed in the last decades. There are several national and international factors that break the monopoly on international law and open the door to the participation of national judges in its development. On the international plane, several phenomena can be pointed out. The expansion of issues regulated by international law, its process of humanisation, its institutionalisation, and its judicialisation, are some of those worth noting.

As is well known, international law long ago ceased to be a merely an inter-state regime. ${ }^{6}$ The issues to be regulated multiplied, so that issues on which States had a monopoly, such as tariffs or the protection of individuals, are now also regulated by international law. ${ }^{7}$ In this context, in many cases today, when regulating or resolving a particular issue, national agents must necessarily use international standards.

In addition to this extension of the subjects regulated by the international law, the process of humanisation took place. Humanisation is the process by which human dignity is recognized as a central value on which the legal order is built. Through this process, international law assumed the role of protecting individuals as one of its main task questioning the voluntarist-statist nature of the juridical order. ${ }^{8}$ The process of humanisation places individuals and the protection of human rights at the centre of international law. It allows the creation of mechanisms of protection with judges as the pillars of these mechanisms. At the same time, this process allows judges to generate necessary changes in the relationship between international and national law to guarantee the protection offered to individuals.

Due to this process of expansion of international law, its institutionalisation and especially its judicialisation are being consolidated. ${ }^{10}$ The need for international authorities to ensure the rule of international law brought about the proliferation of such entities. Thus, from the creation of the Central American Court of Justice in 1907, through the Permanent

Tams, CJ, "Introduction: Domestic Courts as Agents of Development of International Law" 26 Leiden Journal of International Law (2013) 531, 533.

6 As described by Slaughter and Burke-White, the interference of international law in the relationship between the States and its citizens, far away from the classic inter-state regulation, meant a significant change in the evolution of international law. See Slaughter, AM and Burke-White, W, "The Future of International Law is Domestic" in Nollkaemper, A and Nijman, J, eds, New Perspectives on the Divide between International and National Law (Oxford University Press, Oxford, 2007), 110.

7 In the words of Tzanakopoulos, "globalization has augmented the permeability of domestic legal orders, while at the same time it has led to a considerable increase in international regulation. It was only natural then that domestic courts would be faced ever more frequently with having to apply rules promulgated at the international level". Tzanakopoulos, A, "Domestic Courts in International Law: The International Judicial Function of National Courts" 34 Loyola of Los Angeles International and Comparative Law Review (2011) 133 at <digitalcommons.lmu.edu/ilr/vol34/iss1/7> (accessed 22 May 2018).

8 According to Celestino del Arenal, humanization implies, "the progressive consideration of human beings as actors and international legal subjects of international society. It marks a break with the Westphalian logic establishing the sovereign character of the State and the exclusivity of its jurisdiction over its population. Likewise, it is the overcoming of the exclusively State-centric character that traditionally has had the international law". Del Arenal, C, Introducción a las relaciones internacionales (TECNOS, 2007), 342.

9 Acosta Alvarado, PA, "La humanización del derecho internacional en la jurisprudencia interamericana" 7 Anuario de acción humanitaria y derechos humanos - Yearbook of humanitarian action and human rights (2010) 87.

10 According to Cesare Romano, the idea of international law as a set of rules for the correct dispute settlement between States triggered the proliferation of international organizations and bodies. Romano, C, "A Taxonomy of International Rule of Law Institutions", supra nt 5, 251. 
Court of International Justice in 1922, the multiplication of international institutions has accompanied the expansion of international law in the terms already described. ${ }^{11}$

This institutionalisation implies a close interaction between national and international authorities for two reasons. First, the regulatory capacity of international institutions has direct effects on States and the behaviour of their agents. Secondly, and in relation to the above, the actual effectiveness of international institutionality depends to a large extent on the effective cooperation of national authorities. ${ }^{12}$

The judicialisation, which has led to the creation of more than one hundred courts or quasi-jurisdictional bodies in the international arena, ${ }^{13}$ has the same effects. On the one hand, the decisions of international judges often have strong consequences on national institutionality. On the other hand, the effectiveness of decisions necessarily depends on the behaviour of State agents, their application and interpretation of international law (infra III.). ${ }^{14}$

All these changes can be summarized in a very particular dynamic; it can be said that today international law and national law share objectives and objects of regulation. This in turn has led to the articulation of normative, institutional, and interpretative tools for the achievement of these common goals. This new scenario necessarily leads to the rupture of the monopoly over international law. ${ }^{15}$

In parallel, and perhaps because of these international phenomena, national law also undergoes a change that contributes to the mentioned rupture; the constitutional opening to international law, or what has been called by some the internationalisation of constitutional law. This opening is evident in the creation of so-called 'constitutional bridge clauses' or 'clauses of articulation', that is, constitutional rules that allow the articulation of international law and constitutional law. ${ }^{16}$ Here we refer to the constitutional rules that admit the binding force of international obligations, those which prescribe the interpretation of national rules in the light of international commitments, or those that give some international rules, the status of constitutional rules. Such rules necessarily determine that State agents become agents of international law.

11 For a more comprehensive outlook of the evolution and outcome of the international courts see Madsen, MR, "Judicial Globalization and Global Administrative Law: The Particularity of the Proliferation of International Courts" 2015(1) University of Copenhagen Faculty of Law Legal Studies Research Paper Series (2015).

12 Slaughter, AM, \& Burke-White, W, "The Future of International Law is Domestic", supra nt 8, 111.

13 The Project on International Courts and Tribunals (PICT) reported until 200473 active international judicial institutions and 8 more in construction. However, latest research in the field report 142 bodies and procedures. Romano, CPR "A Taxonomy of International Rule of Law Institutions", supra nt 5, 242.

14 Sandholtz, W, "How Domestic Courts Use International Law" 38(2) Fordham International Law Journal (2015) 595, 596; Kanetake, M and Nollkaemper, A, "The Rule of Law at the National and International Levels: Contestations and Deference" in Kanetake, M and Nollkaemper, A, eds, The Rule of Law at the National and International Levels: Contestations and Deference (Hart Publishing, Oxford, 2016).

15 This is precisely what allows Slaughter and Burke-White to say that the future of international law is domestic. Slaughter, AM, and Burke-White, W, "The Future of International Law is Domestic", supra nt 8, 111.

16 Here, we refer to the constitutional rules that admit the binding force of international obligations, those which prescribe the interpretation of national rules in the light of international commitments, or those that give some international rules, the status of constitutional rules. For further information about this topic: Acosta Alvarado, PA, "Zombis vs. Frankenstein: Sobre las relaciones entre el Derecho Internacional y el Derecho Interno" 14(1) Estudios Constitucionales (2016) 15. 
All these national and international phenomena altered and accelerated the dynamics of interaction between national and international law, so that today it is possible to state:

Times have changed. To an extent almost unimaginable even thirty years ago, national courts ... are called upon to consider and resolve issues turning on the correct understanding and application of international law, not on an occasional basis, now and then, but routinely, and often in cases of great importance. ${ }^{17}$

In other words, changes in international law and national law have led to a rupture of the monopoly over international law and opened the door for national judges, as mentioned by Tzanakopoulos, to exercise an international judicial function. ${ }^{18}$ The next section will scrutinise the scenarios in which this happens.

\section{From International to National Interpretation of International Law: The Role of National Judges}

From the classic perspective of international law, the work of national judges has been considered a matter of minimal relevance. ${ }^{19}$ However, the changes that have just been described have led to the recognition of national judges as agents of international law and, ${ }^{20}$ therefore, to the possibility of considering them as more than just enforcers of law. ${ }^{21}$ Their work is something more than a fact. ${ }^{22}$

In this sense, as several authors have shown, ${ }^{23}$ national judges act as agents of international law on different occasions, such as when they resolve disputes using sources of

17 Bingham, T, "Preface" in Fatima, S, Using International Law in Domestic Courts (Hart Publishing, Oxford, 2005), xi, cited by "Introduction: Domestic Courts as Agents of Development of International Law", supra nt 7, 533.

18 Tzanakopoulos, A, "Domestic Courts in International Law: The International Judicial Function of National Courts", supra note 9.

19 Karen Knop express it in the following terms: "the presumption among international lawyers that any particularization of international law in domestic decisions is either isolable (an application of the norm to the facts) or biased (a partial interpretation of the norm) has meant that domestic decisions tend to be given little weight as statements of international law". Knop, K, "Here and There: International Law in Domestic Courts" 32(2) New York University Journal of International Law \& Politics (2000) 501, 532.

20 An outcome of this process of interaction between local and international legal orders is the fertile doctrine focused on international law in domestic courts. Nowadays, a great number of academics support the idea that national judges act as agents of international law. See, inter alia: Roberts, A, "Comparative International Law? The Role of National Courts in Creating and Enforcing International Law" 60(1) The International and Comparative Law Quarterly (2011) 57, 59. See also O'Keefe, R, "Domestic Courts as Agents of Development of the International Law of Jurisdiction" 26(3) Leiden Journal of International Law (2013) 541.

21 As said by Anthea Roberts: "Domestic court decisions are unique within the international law doctrine of sources because of their ability to wear two hats, representing: (1) practice of the forum State, which may be relevant to the determination of custom and the interpretation of treaties (law creation); and (2) a subsidiary means of determining international law, capable of stating international norms with more authority than attends the practice of a single State (law enforcement)". Roberts, A, "Comparative International Law? The Role of National Courts in Creating and Enforcing International Law", supra nt 22, 57.

22 In fact, for Nollkaemper, the national judges, "may indeed compensate for the lack of international courts as a systemic force in the protection of the international rule of law". National Courts and the International Rule of Law, supra nt 4,8 .

23 Among others, see: Waters, MA, "Mediating Norms and Identity: The Role of Transnational Judicial Dialogue in Creating and Enforcing International Law" 93(2) The Georgetown Law Journal (2005) 487; 
international law, when exercising constitutional or legality control, and when complying or refusing to comply with international obligations or orders of international courts.

With respect to the judges role as arbitrators, the proliferation of international commitments and their growing influence in the domestic legal order increases the occasions in which national judges fail to apply international norms, ${ }^{24}$ either to resolve contradictions between them and domestic rules, or to resolve cases using international law. ${ }^{25}$ The truth is that there are several occasions in which national judges are confronted with situations regulated by national and international norms, hybrid conflicts for the solution of which parameters of both origins must be considered.

Secondly, considering certain clauses of articulation between national and international law, international standards have become a parameter for the control of constitutionality and for the control of legality at the national level. ${ }^{26}$ In this sense, some domestic judges exercise control of the legality of acts belonging to the national and international legal order, in light of international obligations, ${ }^{27}$ to guarantee their conformity therewith. ${ }^{28}$ In this context, '[t]he sanction of [ir] responsibility thus supports the power of national courts to ensure an act which would be internationally wrongful, were it to take place, does not occur'. ${ }^{29}$

Finally, national courts must necessarily operate with international law when they are the recipients of orders from international institutions. This is the case, for example, when a human rights court orders a national judge to reopen a case to try it in the light of

Benvenisti, E, \& Downs, GW, "National Courts, Domestic Democracy, and the Evolution of International Law" 20(1) European Journal of International Law (2009) 59; Tzanakopoulos, A, "Domestic Courts in International Law: The International Judicial Function of National Courts", supra nt 9.

As asserted by Tzanakopoulos and Tams: "Both factors - increasing scope, and increasingly inwardoriented reach - explain why domestic courts today routinely engage with international law. It is against this background that inquiries into the law-developing function of domestic decisions are called for." "Introduction: Domestic Courts as Agents of Development of International Law", supra nt 7, 534; National Courts and the International Rule of Law, supra nt 4, 9.

25 In Colombia, particularly, the use of international rules depends of the regime to which it belongs. The use of human rights law is increasing, mainly those related with the inter-American system for the protection of human rights, thanks to the conventionality control. Instead, the use explicit use of rules regarding to international economic law remains scarce. For a deeper analysis, see: Acosta Alvarado, PA, Acosta López, JI, and Huertas Cárdenas, JE, "Conclusiones generales del proyecto de investigación" in Acosta Alvarado, PA, Acosta López, JI, and Rivas Ramírez, D, De anacronismo y vaticinio: Diagnóstico de las relaciones entre el derecho internacional y el derecho interno en Latinoamérica (Universidad Externado de Colombia, Bogotá, 2017)

26 Acosta Alvarado, PA "Zombis vs. Frankenstein: Sobre las relaciones entre el Derecho Internacional y el Derecho Interno", supra nt 18, 15.

27 As asserted Mathias Kumm: "If national constitutional courts are willing to strike down laws passed by the national legislature, then they should have the institutional clout to do the same thing when enforcing international law". Kumm, M, "International Law in National Courts: The International Rule of Law and the Limits of the Internationalist Model" 44 Virginia Journal of International Law (2003) 19, 22-24.

28 Nollkaemper asserts: "First, as organs of the State, national courts may commit an international wrong on behalf of their State by decisions that violate international law or may fail to correct wrongs committed by the organs of the State. Secondly, from the principle that national courts should prevent their States acting in contravention of international obligations, a court may infer that it should assume and exercise jurisdiction to do so". National Courts and the International Rule of Law, supra nt 4, 42, 43.

29 Ibid. In the same direction: "Domestic Courts in International Law: The International Judicial Function of National Courts", supra nt 9, 156. 
international protection standards or when a Court of a supranational regime orders the judge to rule on a case involving international standards in a particular way (infra IV.).

However, regarding the latter, national courts may also serve to avoid the fulfilment of international obligations. This has occurred, for example, in the cases of Venezuelan ${ }^{30}$ and Dominican $^{31}$ judges with respect to inter-American obligations or in the event of the Ecuadorian $^{32}$ and Colombian courts in relation to the rules of protection of foreign investment or matters of maritime delimitation. ${ }^{33}$

In this context, as Nollkaemper affirms, '[n]ational courts operate neither fully in the national nor fully in the international legal order, but rather in a mixed zone where they are subject to competing loyalties, commitments, and obligations. ${ }^{34}$ In addition, Roberts raises similarly that '[n]ational court decisions alone have the potential to wear both hats and thus their value is often considered to be mixed. ${ }^{35}$

Now, beyond the features of the various scenarios in which the national judge operates as an agent of international law, the next section seeks to highlight the consequences this has on international law.

\section{International Law Under the Lens of National Judges}

Yet the international law that is being embraced does not remain unchanged: in the embrace, it is domesticated. ${ }^{36}$

Regarding the effects of the work of the national judge on international law, we can distinguish two different scenarios. On the one hand, the traditional notion that national judicial decisions serve to determine the existence of certain rules of international law or to compromise the international responsibility of the State. On the other hand, a much more active role of national judges, according to which their work is fundamental to determining the content of international obligations and establishing their limits ${ }^{37}$, to facilitate the systemic interpretation of the various regimes of international law, to ensure the effectiveness of international law, and, in general, to change the logic of relationship between the two legal systems. ${ }^{38}$ In the context of the debate about identification or

\footnotetext{
Supreme Court of Justice of Venezuela, Constitutional Chamber, 1572/2008.

Constitutional Court of Dominican Republic, TC/0256/14.

Provincial Courts of Sucumbíos, 14 February 2011; Ecuador National Court of Justice, 6 August 2012.

Constitutional Court of Colombia, C-240/14.

National Courts and the International Rule of Law, supra nt 4, 14.

35 "Comparative International Law? The Role of National Courts in Creating and Enforcing International Law", supra nt 22, 63.

36 "Introduction: Domestic Courts as Agents of Development of International Law", supra nt 7, 534.

37 As is well known, the rules of international law are generally written in general terms. It is in this context that the work of the national judge plays a fundamental role. Their choices may specify the content of a rule whose scope has not been determined. However, the work of the national judge also serves to prove the existence of norms of international law, such as custom and general principles. On these matters see, among others: UN General Assembly, Report of the International Law Commission on the Work of Its Sixty-Seventh Session, 2015, (70th plenary session) A/70/10 Supp No 10, 9, para 4. This report and other ILC documents are available online at <legal.un.org/ilc> Accessed on 22 May 2018; Roberts, A, "Comparative International Law? The Role of National Courts in Creating and Enforcing International Law" Supra nt 22, 57; Tzanakopoulos, A, supra nt 9, 154 and further.

38 In the words of Anthea Roberts: "Domestic court decisions are unique within the international law doctrine of sources because of their ability to wear two hats, representing: (1) practice of the forum State, which may
} 
determination of legal international contents, we highlight the capacity of national judges to crystallise the contents of an international obligation, with regard to its application to a particular case.

Regarding the role of the national judge in the traditional reading of international law, there is not much new to say. ${ }^{39}$ It is enough to review the classic manuals to figure out that the decisions of national judges can serve as evidence of a State's behaviour when proving one or both of the constituent elements of international custom ${ }^{40}$ or in helping to crystallize the general principles of international law. ${ }^{41}$ Likewise, no-one questions the possibility that the behaviour of national judges may engage the international responsibility of the State. ${ }^{42}$

However, this is not the discourse this paper seeks to analyse. Instead, the focus is on the increasingly pronounced functions of the national judge's work in international law. In the first place, we would like to highlight that every time national judges operate with international standards in their daily work, they may have the opportunity to determine the content - or even the existence ${ }^{43}$ - of international obligations and, sometimes, establish their limits.

In other words, national judges play an important role in the interpretation, determination, and development of international law. ${ }^{44}$ In exercising their role of deciding

be relevant to the determination of custom and the interpretation of treaties (law creation); and (2) a subsidiary means of determining international law, capable of stating international norms with more authority than attends the practice of a single State (law enforcement)". Roberts, A, supra nt 22, 59.

39 As said by Tzanakopoulos, "It is a trite observation that domestic courts, as State organs, produce State practice and utter opinio juris, and are therefore capable of creating or contributing to the creation of customary norms." Tzanakopoulos, A, supra nt 9, 155.

40 Both the International Law Commission and the Dutch Advisory Committee on Issues of Public International Law have recognized that the decisions of domestic courts may be useful for the identification of international customary law, as long as they serve as forms of evidence of the constitutive elements (both of them) of rules of customary international law, or as subsidiary means for the determination of such rules. See: Advisory Committee on Issues of Public International Law, REPORT: Advisory Report on the identification of customary international law, Advisory report No 29, November 2017, 9-12. And: International Law Commission, Identification of customary international law - The role of decisions of national courts in the case law of international courts and tribunals of a universal character for the purpose of the determination of customary international law, A/CN 4/691, 9 February 2016, 32, observation 23.

41 It could be enough to look through the d'Aspremont, J and Besson, S, The Oxford Handbook of the Sources of International Law (Oxford University Press, Oxford, 2017). It can be seen also, among others: Medelson, $\mathrm{MH}$, "The formation of International Customary Law" in 272 Recueil des course de l'Academie de Droit Internationale de la Haye (1998); International Law Association, London Statement for Principles Applicable to the Formation of General Customary International Law (2000), 9; Cassese, A, International Law (Oxford University Press, Oxford, 2001); Brownlie, I, Principles of Public International Law (Oxford University Press, Oxford, 2008).

42 A proof of this are the rules about the international responsibility of States. See: UN General Assembly, Draft articles on Responsibility of States for Internationally Wrongful Acts, 12 December 2001, (85th plenary meeting) A/RES/56/83, chapter II, article 4.

43 In this respect, Nollkaemper shows how the judgements of national judges constitute an autonomous source of authority in international law. In his own words: "The traditional perspective, in which they are part of national law and as such "just" facts, co-exists with a newer perspective, in which the increasing independence and empowerment of national courts allows the international legal order to treat them to some extent as autonomous sources of authority". National Courts and the International Rule of Law, supra nt $4,266$.

44 In words of Nollkaemper, "By interpreting and applying international obligations, national courts may facilitate the determination of the contents of such obligations and may contribute to their development. 
disputes that involve international norms, they construct jurisprudence that constitutes an input for the development of international law itself. A clear example of this function is the evolution of the rules of international law concerning immunities of States and State officials, whose main input, since the nineteenth century, are the decisions of domestic courts in this regard. ${ }^{45}$

Indeed, the practice of these judges and international judges in assessing the decisions handed down by their domestic peers shows that national decisions often constitute instruments for the evolution of international law by going beyond the mere application according to the current State of international judicial interpretation. Important Cases in the matter, such as that of Pinochet in the House of Lords of the United Kingdom, ${ }^{46}$ or the one of Ferrini vs. Federal Republic of Germany before the Italian Supreme Court of Cassation, ${ }^{47}$ reflect the creative capacity of these judges as an instrument of legal evolution. ${ }^{48}$ Another example of the ability of the national judge to determine the scope of international obligations can be found in the Latin American context in the case law regarding prior consultation. As is well known, Convention 169 of the International Labor Organization stipulates the basic obligations of States with respect to the protection of indigenous and tribal peoples. Article 7.1 establishes the duty to advance what is now known as prior consultation, that is, the duty to consult with indigenous peoples on any decision that may

Other national courts and to a lesser extent international courts may rely on that practice for their own determination and interpretation of international law". National Courts and the International Rule of Law, supra nt 4, 10, 264.

45 Van Alebeek, R, "Domestic Courts as Agents of Development of International Immunity Rules" 26(3) Leiden Journal of International Law (2013) 559; in this vein, Roberts, A, supra nt 22, 69-70. There, Roberts highlights the importance of some judgement from domestic courts for the development of the prohibition of torture as a ius cogens rule, and to the evolution of the European Court of Human Rights precedent, among other things.

46 In this case, the Lords Chamber decided, based on some rules of the UN Convention Against Torture, that a head of State could not argue official immunity in the context of torture denouncements. This unprecedented decision back then (1999) determined the evolution of international law in this regard and modified the existing understanding of the immunity for state officials, from then on. Therefore, the decision of a national court in this case fostered the evolution of international law in this regard, what prove our viewpoint about the capacity of national judges to develop and create international law in a particular case. For a deeper analysis, see: Roberts, A, supra nt 22, 58.

47 In this case (2004), the Italian court asserted that it was possible to apply universal jurisdiction with regard to civil liability against the German State, because of the nature of the acts committed, particularly international crimes that take the form of serious human rights violations (In the case, Ferrini filed a civil action against the Federal Republic of Germany for the damaged caused on account of his imprisonment, deportation, and forced labour). Moreover, the court found that the rights protected under international criminals and human rights law, prevail over the norms regarding State immunity. As the case of Pinochet, Ferrini was an unprecedented decision in 2006, since it promoted the idea of a universal jurisdiction whenever an international crime was committed. See: Ferrini v Federal Republic of Germany (2006) 128 International Law Review 658. Corte di Cassazione (Sezioni Unite), Ferrini v Federal Republic of Germany, Judgment No 5044, 6 November 2003, registered 11 March 2004, paras 9, 11.

For more information about this case: Roberts, A in "Comparative International Law? The Role of National Courts in Creating and Enforcing International Law", supra nt 22, 64

48 As shown in the cases above, this aforementioned evolution of international law by means of decisions from national courts may produce different results in a way such as to allow contra legem interpretations in a particular case. As long as the decision find the need for defeasibility of a rule in the case, it may apply a legal consequence that is no provided by the existing rule, but which may be more suitable for the judgement. 
affect them. ${ }^{49}$ Given the breadth of this standard, the profile of the prior consultation was quite indeterminate. However, thanks to the interpretation of the national judges of the region, ${ }^{50}$ which was adopted by the -Interamerican Court ${ }^{51}$ itself which interpreted, in turn, the obligations of the ACHR, ${ }^{52}$ it was possible to establish the scope of the State obligation provided for in Convention 169 as well as in the Pact of San José. ${ }^{53}$

Nonetheless, the work of the national judge also serves to set limits to international commitments. Thus, for example, the case-law of European national judges concerning the idea of constitutional identity ${ }^{54}$ as a limit to the scope of Community rules, ${ }^{55}$ or the decision of an Italian national court to disregard State immunity to consider itself to have jurisdiction in a labour dispute. ${ }^{56}$

Secondly, the national judge acts as a piece of articulation of international law. As is well known, the proliferation of international regimes, and thus of institutions and tribunals, has led to dissimilar and even contradictory applications of international obligations. ${ }^{57}$ In this scenario of fragmentation, the national judge serves as a common denominator, who, being bound by all regimes without distinction, must necessarily achieve, as far as possible, a harmonious interpretation of the obligations that bind him. In other words, the work of the national judge is undoubtedly the mechanism par excellence for the systemic interpretation of international law.

49 ILO Convention 169. Article 7(1). "The peoples concerned shall have the right to decide their own priorities for the process of development as it affects their lives, beliefs, institutions and spiritual wellbeing and the lands they occupy or otherwise use, and to exercise control, to the extent possible, over their own economic, social and cultural development. In addition, they shall participate in the formulation, implementation and evaluation of plans and programmes for national and regional development which may affect them directly".

50 Corte Interamericana de Derechos Humanos, Pueblo Indigena Kichwa de Sarayaku V. Ecuador, IACtHR Series C No 245, 27 June 2012, paras 164-167.

51 Pueblo Indigena Kichwa de Sarayaku V. Ecuador, paras 164-167.

52 Inter-American Specialized Conference on Human Rights, American Convention on Human Rights, 22 November 1969, articles 1.1, 4, 5, 13, 21, 23 and 26.

53 See, also: Corte Interamericana de Derechos Humanos, Comunidad Garifuna Triunfo de la Cruz y sus miembros Vs Honduras, IACtHR Series C No 305, 8 October 2015; Corte Interamericana de Derechos Humanos, Comunidad Garifuna de Punta Piedra y sus miembros Vs Honduras, IACtHR Series C No 304, 8 October 2015; Corte Interamericana de Derechos Humanos, Comunidad Indigena Xákmok Kásek Vs Paraguay, IACtHR Series C No 214, 24 August 2010.

54 In this respect, the Solange and Gorgülu cases from the Bundesverfassungsgericht show how a domestic judge denies to give effect to an European judgement in pursuit of the protection of the individual's fundamental rights under the German constitution. For a deep analysis: Nollkaemper, A, "Rethinking the supremacy of international law" 65(1) Zeitschrift für öffentliches Recht (2010) 65, 76.

55 Among the dozens of documents on this issue, can be checked: Faraguna, P, "Constitutional Identity - A Shield or a Sword? The Dilemma of Constitutional Identities in the EU" 18(7) German Law Journal (2017) at <ssrn.com/abstract=2995416>(accessed 22 May 2018); Cloots, E, "National Identity, Constitutional Identity, and Sovereignty in the EU" 2 Netherlands Journal of Legal Philosophy (2016) 82; Flores Amaiquema, JA, "National Constitutional Identity in the European Union and the Principle of Primacy" (LLM Final Thesis in Natural Resources and International Environmental Law, December 2015) at <skemman.is/bitstream/1946/23411/3/Final\%20Thesis.pdf> (accessed 22 May 2018).

56 Court of Cassation, All Civil Sections, Drago v International Plant Genetic Resources Institute (IPGRI), Final Appeal Judgement, No 3718, cited by "Rethinking the supremacy of international law", supra nt 56, 77.

57 Koskenniemi, M, and Leino, P, "Fragmentation of international law? Postmodern anxieties" 15 Leiden Journal of International Law (2002) 553, 554. 
With respect to this problem, two questions may arise. First, what about dualistic states? Second, does the risk of fragmentation increase if we leave the work of interpretation in the hands of national judges? Regarding the former, the idea of the national judge as the piece of harmonisation between national law and international law does not vary according to the type of State (dualist or monistic), since it depends on whether international law is binding on the national officer, regardless of the way in which such linkage arises. Of course, its role as harmoniser vanishes if it is not linked to the international standard and, in that event, the task of harmonisation depends exclusively on international operators. This leaves aside the debate on the uselessness of the dualism-monism binomial, which we cannot deal with now.Regarding the second, it is worth remembering that the work of national judges has not been done in a vacuum. Their use of international law should always consider what international operators have said on following the rules of interpretation of international law. In this sense, their work is nothing more than the hinge that makes a coherent interpretation possible. Besides, the risks of fragmentation that can occur in facing the dissimilar voice of the different national judges that reproduce the international scenario of never-ending debate. The answer for them is the same, systemic interpretation. From our point of view, what is important is not the longing for the false pretence of uniformity based on the fallacy of the universal vocation of international law, but the adequacy of the use of international law to the scenario and the needs to which it is being applied; and this, without a doubt, can be achieved by the national judge.

In some cases, in view of the need to coordinate, for example, the protection of the environment with the guarantee of the rights of foreign investors, it is necessary for the national court to articulate international obligations to maximise their effectiveness. ${ }^{58}$ The same may happen where tension arises between the guarantee of human rights and the rights of foreign investors. ${ }^{59}$

Furthermore, when deciding the constitutionality of the ratification of a treaty, a national court can declare its unconstitutionality due to the failure to fulfil other international obligations. ${ }^{60}$ In Colombia, for example, the Constitutional Court has tried to interpret or limit the extent and effect of an international obligation, taking into consideration other international binding rules. ${ }^{61}$

Third, and hand in hand with the above, many times the work of the national judge is indispensable to ensure the effectiveness of international law. In this sense, we must distinguish between effectiveness in the strict and in the broad sense. National judges are

58 For example, the Constitutional Court of Colombia decided to forbid the mining activities in sensitive ecosystems, because they provide more than $70 \%$ of the drinkable water. See: Constitutional Court of Colombia, C-035/2016.

59 In another case, the Constitutional Court of Colombia decided to suspend a mining Project to protect the right of some ethnic group to prior consultation under the ILO's Convention No 169. See: Constitutional Court of Colombia, SU-133/2017.

60 Constitutional Court of Colombia, C-915/2010; Constitutional Court of Colombia, C-196/2012; Constitutional Court of Colombia, C-1051/2012.

61 See also: Lozada Gomez, M, "Decisiones de la Corte Constitucional relativas a derechos de inversionistas extranjeros: ¿Insumo para la defensa internacional del Estado colombiano en materia de inversión, o fuente de incumplimiento internacional?" in La defensa internacional de los intereses del Estado en América Latina (Universitad Externado de Colombia, Bogotá, forthcoming). 
often subject to international obligations directly whether they derive from a treaty, ${ }^{62}$ custom or other source of international law or, on the contrary, from international authorities. ${ }^{63} \mathrm{In}$ this context, the behaviour of the national judge depends on the strict compliance with an explicit mandate addressed to him. Consider, for example, those cases in which an international judge orders a national judge to (re-)open judicial proceedings since the rules that served as the basis were contrary to international law or because the international standards of due process were not met. In both events, the international order aims to fulfil international obligation and the non-compliance by national judges would imply the inefficacy of the norm.

In Latin America a very telling example of this dynamic exists; these are the judgments of the Inter-American Court that order national judges to (re-)open processes to investigate, prosecute and punish those accountable for serious human rights violations who have been beneficiaries of an amnesty law. ${ }^{64}$ The basis of this order is the compliance with the duty of States to adapt their legal orders to the obligations derived from the covenant(Article 2 of the ACHR) and the guarantee of the rights of victims (Articles 8, 25 and 63 of the ACHR). In these cases, several national judges - these being (Peru, ${ }^{65} \mathrm{Chile}^{66}$ and even without a direct order Argentina ${ }^{67}$ ) - responded to the appeal of the Court, but others - (Uruguay and Brazil) - refused to invalidate the amnesty law and, therefore, did not (re-)open the judicial proceedings. ${ }^{68}$

In these cases, there is an international obligation that explicitly attributes a responsibility to the national judge (to control the compliance of the amnesty law with the ACHR), along with a direct order from an international body which is also addressed to the national judge (aimed at reopening the case and prosecuting the possible aggressors). In both events the efficacy of them (norm and order) is in the hands of the domestic judge.

However, even if international obligations or orders are not directed explicitly to national judges, their work is fundamental in securing the ultimate purpose of an international norm. Thus, for example, when national judges determine the unconstitutionality or illegality of a national rule whenever it breaches international

62 Eg. Council of Europe, European Convention for the Protection of Human Rights and Fundamental Freedoms, as amended by Protocols Nos 11 and 14 (1950) ETS 5 (ECHR), article 6.1; American Convention on Human Rights, article 8.1.

63 For example, the Inter-American Court of Human Rights usually includes in his judgements a set of specific orders for the national judges. This orders often seek the prosecution and judgment of those responsible of human rights violations that entailed the international responsibility of the State. About the importance of national judges to ensure the effectiveness of the orders of international judges, see, inter alia: Huneeus, A, "Rejecting the Inter-American court: Judicialization, national courts, and regional human rights" No 1167 Legal Studies Research Paper Series, Wisconsin University (2010).

64 IACtHR, Gelman Vs. Uruguay, IACtHR Series C No 221, 24 February 2011; IACtHR, Gomes Lund y otros (Guerrilha do Araguaia) Vs. Brasil, IACtHR Series C No 219, 24 November 2010; IACtHR, Almonacid Arellano y otros Vs. Chile, IACtHR Series C No 154, 26 September 2006; IACtHR, Goiburu y otros Vs. Paraguay, IACtHR Series C No 153, 22 September 2006; IACtHR, Barrios Altos Vs. Perú, IACtHR Series C No 75, 14 March 2001.

65 Supreme Court of Justice (Peru), Causa No 19-2001-AV, 7 April 2009.

66 Supreme Court of Justice (Chile), Causa No 559-04, 13 December 2006; Supreme Court of Justice (Chile), Causa No 2666-04, 18 December 2006; Supreme Court of Justice (Chile), Causa No 559-04, 13 December 2006.

67 Supreme Court of Justice of the Nation (Argentina), Causa No 17/768, 14 June 2005, paras 23, 27, 29.

68 On this issue, see: IACtHR, Gomes Lund y otros (Guerrilha do Araguaia) Vs. Brasil, Resolution of 17 October 2014; IACtHR, Gelman Vs. Uruguay, Resolution of 20 March 2013. 
obligations, they are ensuring respect for the effectiveness of the latter. In this context, the cases of Beit Sourik Village Council v The Government of Israel ${ }^{69}$ and Narmada Bachao Aandolan v India ${ }^{70}$ can be mentioned among others. ${ }^{71}$

Something similar occurs when national judges integrate international standards as a basis for the orders they address to other State agents. Thus, for example, the orders of the Colombian Constitutional Court in the context of decisions ordering regulatory, budgetary and institutional adjustments to protect the displaced population or the prison population, ${ }^{72}$ the orders of the Bolivian judge ordering the protection of the rights of indigenous peoples, ${ }^{73}$ or the decisions of the Argentinian judges who reopened the cases of the dictatorship ${ }^{74}$.

Moreover, it is reasonable to think that any order of a national judge which has consequences on the fulfilment of an international obligation have a similar effect, even if that effect is not contemplated or is not obvious. This is the case, for example, with the decisions of national judges who impose fines on service operators whose capital is foreign, ${ }^{75}$ or those that prohibit certain types of investment in areas protected by environmental regulation. ${ }^{76}$ In these examples the effectiveness of international law may be at risk even without the judicial decisions involving or contemplating the interpretation or application of international norms specifically.

As can be seen, the scenarios in which the national judge must rule on norms of international law, and along with the consequences that this has on international law, are vast. It could even be said, as Nollkaemper affirms, that decisions of national judges in relation to international law outnumber those of the international tribunals themselves. Therefore, "national case law has a more profound effect on the current application of international law, and the protection of the international rule of law, than on the decisions of international courts and tribunals' . ${ }^{77}$

As has previously been mentioned, ${ }^{78}$ in view of this new context, the work of the national judge is essential to construct a new theoretical model and with it new ways to explain and determine the relationship between the two legal systems. The efficacy of international law undoubtedly depends on the profile of this relationship. The following section reviews the particular scenario of foreign investment law in Latin America. This places particular context on what has been said so far.

69 Supreme Court (Israel), Beit Sourik Village Council v. The Government of Israel et. al., HCJ 2056/04, 20 June 2004.

70 Supreme Court of India, Narmada Bachao Andolan v. Union of India, Writ petition (civil) No 319 of 1994, AIR 2000 SC 3751, 18 October 2000.

71 National Courts and the International Rule of Law, supra nt 4, 7.

72 Constitutional Court of Colombia, T-025/2004; Constitutional Court of Colombia, T-049/2016.

73 Constitutional Plurinational Tribunal of Bolivia, SC 2003/2010-R, 25 October 2010; Constitutional Plurinational Tribunal, SC 0300/2012, 18 June 2012.

74 Supreme Court of Justice of the Nation (Argentina), 14 June 2005, Causa No 17/768, paras. 23, 27, 29.

75 Constitutional Court of Colombia, SU-263/15; Constitutional Court of Colombia, T-783/2013. Same

76 Constitutional Court of Colombia, C-035/2016.

77 National Courts and the International Rule of Law, supra nt 4, 8.

78 De anacronismo y vaticinio: Diagnóstico de las relaciones entre el derecho internacional y el derecho interno en Latinoamérica, supra nt 27. As well as: Acosta Alvarado, PA, supra nt 18, 15. 


\section{The Case of Foreign Investment Law in Latin America: A Growing Concern for National Judges}

The different causes of the growing and daily engagement of national judges with sources of international law has been analysed. Moreover, the effects of national judges' intervention in terms of the interpretation and development of international law have been explored. In this vein, the case of foreign investment law in Latin America will be utilised to show how national judges are dealing with these rules of international origin and to define the extent to which some of its standards are applied in this region.

As can be discerned from statistics released by the International Centre for Settlement of Investment Disputes (ICSID) in 2017, ${ }^{79}$ Latin America has been, and continues to be, one of the most (if not the most) sued region under international investment agreements. Hence, the countries of this region had several investment awards rendered against them and have had to deal with the correct enforcement of foreign investment law in their national legal orders.

Moreover, as shown correctly by Van Harten, these international tribunals have de facto taken over the core of the judicial function in public law, ${ }^{80}$ due to the large scope of investment standards and the reluctance of these arbitrators to show deference or restraint when overseeing national decisions. This has led to concerns of domestic courts about the effects and scope of international investment agreements, regarding their national legal framework.

In this way, the phenomena of judicialisation and expansion of international law are evident in the features of foreign investment law. Therefore, the national judges are reacting to this process, and have started to make decisions whilst taking into account investment standards. A proof of this reply is the practice of domestic courts in Latin America, ${ }^{81}$ which shows that they are applying international investment standards to settle diverse issues and to control the legality of national rules emanating from both the executive and the legislature. ${ }^{82}$ Furthermore, some of these judges apply rules from bilateral investment treaties BITs and Free Trade Agreement (FTA) which are binding on their States, and some have even been recognised by the international arbitrators as capable of guaranteeing the rights of foreign investors. ${ }^{83}$

Although the judges' engagement with investment rules depends on the dispute settlement clauses negotiated by each State and the feasibility of the direct application of

79 The International Centre for Settlement of Investment Disputes (ICSID), REPORT: The ICSID CaseloadStatistics 2017(2) [Washington DC], 30 June 2017, at <icsid.worldbank.org/en/Documents/resources/ICS ID\%20Web\%20Stats\%202017-2\%20(English)\%20Final.pdf> 11, 26 (accessed 22 May 2018).

80 Van Harten, G, Investment Treaty Arbitration and Public Law (Oxford University Press, Oxford, 2007 ), 44.

81 See: Yimer, B, Cisneros, N, Bisiani, L, and Donde, R, "Application of International Investment Agreements by Domestic Courts" E780 Trade Law Clinic (2011) at <academia.edu/8462787/Application_of_International_ Investment_Agreements_by_Domestic_Courts_UNCTAD_> (accessed 22 May 2018).

82 Puig, S, "Investor-state tribunals and constitutional courts: The Mexican sweeteners saga" 5(2) Mexican Law Review México (2013), 228.

83 Saco, V, "The Secret of Peru's Success before the ICSID: Dispelling the Idea that the Investor-State Dispute Settlement System is a Danger for Developing Countries/El secreto del éxito del Perú en el ciadi: destruyendo el paradigma de que el sistema de solución de diferencias inversionista-Estado es peligroso para los países en desarrollo" in Tanzi, A, Asteriti, A, Polanco Lazo, R and Turrini, P, International Investment Law in Latin America: Problems and Prospects / Derecho Internacional de las Inversiones en América Latina: Problemas y Perspectivas (Martinus Nijhoff, Leiden, 2016), 662. 
these kinds of rule in each legal regime, it can certainly be affirmed that national judges are dealing with foreign investment law. In countries such as Argentina, Venezuela and Mexico, judges have found no objection to apply investment provisions invoked by petitioners to rule in a particular case or to decide whether or not to strike down a domestic rule. ${ }^{84}$

In a case ruled by the Mexican Supreme Court ${ }^{85}$, the Court decided to invalidate a decree that expropriated some sugar mills in Mexico, affecting the property rights of GAMI Investments Inc., a US corporation. In the case, the Court sided with the petitioners, and ensured the constitutional norms and international rules that banned any expropriation without fair compensation. However, the same corporation brought a claim before the NAFTA tribunal, asking for damages. However, it was the international tribunal which denied the protection, under the consideration that there had been no substantial damage from the Mexican government. Consequently, in this case the national courts enforced the international obligations, even more so than the international body.

In other cases, national judges have shown a lackadaisical attitude in this regard, being reluctant to interpret and directly apply investment provisions of international agreements. Nevertheless, this does in no way mean that they are not interfering with and deciding the extent of the rights of foreign investors. As above mentioned, sometimes national judges do not explicitly use international rules, even though their decisions actually have an impact on the scope of international obligations ${ }^{86}$.

In Colombia, particularly, the Constitutional Court has affected the economic rights of foreign investors, while trying to ensure the effectiveness of international obligations outside the foreign investment regime. For instance, in a case regarding the unconstitutionality of a national decree that allowed mining extraction in special ecosystems which provide most of the consumable water in Colombia (ecosystems called paramos), the court declared the unconstitutionality of the rule, and prohibited the exploitations of those territories.$^{87}$ However, the court used some rules from international treaties regarding the protection of human rights and the environment, yet never considered the existence of international obligations vis-à-vis the protection of foreign investors with valid exploitation licenses. Therefore, a Canadian investor, named Eco Oro Minerals, brought a claim before the ICSID, under some provisions on the FTA between Canada and Colombia ${ }^{88}$ which is still pending for decision. After the decisions of the Constitutional Court, foreign investors have brought claims before the ICSID in at least four times. ${ }^{89}$

Besides the already mentioned processes of judicialisation and expansion of international law, it must be said that the fragmentation of international law can play an important role to trigger the intervention of national judges in the application of the clauses available in foreign investment law. In fact, some of the aforementioned uses of investment

84 Investment Treaty Arbitration and Public Law, supra nt 83, 22, 60.

85 SCJN (pleno), Fomento Azucarero Mexicano et al, AR 1132/2004 at <scjn.gob.mx> (accessed 22 May 2018). Cited in: "Investor-state tribunals and constitutional courts: The Mexican sweeteners saga", supra nt 85,225 .

86 This is the case of the Constitutional Court of Colombia, which have affected in at least 4 judgements the rights of foreign investors under FTA's and BIT's, without even mentioning it.

87 Constitutional Court of Colombia, C-035/16, Reporting Judge: Gloria Stella Ortiz Delgado.

88 For more details of the case, see the profile in italaw: italaw, Tribunal, Eco Oro Minerals Corp. v. Republic of Colombia, ICSID CaseNo. ARB/16/41, at<italaw.com/cases/6320> (accessed May 222018

89 These are the cases of: Eco Oro Minerals, América Móvil, Gran Colombia Gold, and Cosigo Resources y Tobie Mining and Energy Inc. 
provisions by national judges seek to enforce these kinds of rules in a reasonable manner; that is to say, in a way that seeks to leave room for the guarantee of other international obligations or constitutional values. ${ }^{90}$

In summary, national judges are increasingly determining the scope and effect of foreign investment law in their national legal orders even if this leads to a troubling number of international claims before international tribunals. In this way, the aforementioned phenomena have triggered the intervention of national judges. Nevertheless, a dialogue between the judges of Latin America is desirable, as it will allow them to develop a clearer understanding of investment provisions before arbitral tribunals ${ }^{91}$.

\section{Final Remarks}

A few years ago, the central question in the debate on the role of national judges with respect to international law was if domestic courts could fulfil some function of international adjudication. Today, however, that debate has been overcome. No one questions that national judges are agents of international law and that the application, interpretation and evolution of international rules largely depends on their work. Thus, as previously stated elsewhere, national judges are not merely one component in a multilevel scheme of adjudicationor, ${ }^{92}$ in the words of Tzanakopoulos, an 'integrated [judicial] architecture' ${ }^{93}$

The advantages of this new scenario are limited. For now, it is worth noting three of these advantages, which stand out throughout this article. To start off with, the work of the national judge facilitates the effectiveness of international law. When national judges interpret international norms, from their reality, considering the characteristics and needs of their legal order, they pave the way for the fulfilment of these international obligations. Moreover, the national judges also ensure the effectiveness of international rules when, in exercise of their jurisdiction, exert control of national and even international standards to guarantee compliance with international obligations. What is more, national judges also improve the effectiveness of international rules, when, acting as direct recipients of an international obligation, decide to execute it. In any event national judges facilitate the compliance of international obligations, even when they give sufficient reasons to 'breach' an international obligation, as the debate around such decision can lead to a more efficient fulfilment of the objectives pursued.

90 This is particularly relevant in the cases from Mexico and Colombia, where the domestic courts have decided to protect human rights, constitutional values, or the environment, at the expense of the rights of foreign investors. Off course this has led to an array of claims before investor-state tribunals, but domestic courts are still judging that way.

91 According to Nollkaemper: "The strengthened position of national courts, including their independence, as well as the apparent quality of decisions from various States, makes it unfruitful to continue to rest the analyses of the legal effect of decisions of national courts on the assumptions. In certain cases, such decisions can be considered as impartial expressions of what these courts believe to be the State of the law. In particular, when these is a certain convergence between decisions of domestic courts, or otherwise a chain of other law-making acts, decisions may achieve a certain authority as to the determination or interpretation of the law that may not be explained in terms of customary law or general principles of law". Nollkaemper, A, supra nt 4, 278.

92 Acosta, PA, Diálogo judicial y constitutionalismo multinivel. El caso de la Red judicial Interamericana (Universidad Externado de Colombia, Bogotá, 2014).

93 "Domestic Courts in International Law: The International Judicial Function of National Courts", supra nt $9,162$. 
Additionally, national judges can be key in clarifying or even avoiding the harmful effects of the supposed fragmentation of international law. As we have seen, there are many occasions in which the national court faces cases in which the effectiveness of the rules of different international regimes is at stake at the same time. Given these scenarios, it is desirable, or better said, necessary that judges take an active role in the consistent interpretation of international law. The fragmentation of international law has triggered the action of national judges as they are the mediators between different international regimes. Furthermore, the development of national legal orders in a context of fragmentation relies exclusively on the efforts of these domestic judges.

Finally, national judges can be essential in determining the what, when, and how of many abstract international rules. Considering the difficult dynamics of the sources of international law, this work of concretisation cannot be underestimated.

Despite the advantages of this new role of the national judge, this new scenario raises new questions. Now one must worry about the how and what of the national judges' function of international adjudication.

As for 'the what', the question will always be how far national judges can go. Whether their decisions imply evolution or, conversely, rupture of international law? What can national judges do as agents of international law? On this matter one may assume the position of Tzanakopoulos, ${ }^{94}$ in the end, everything depends on the reactions generated by the decision of the national judge. What may at first sight be considered a rupture may in fact not be considered as such upon closer examination and may open space for the evolution of international law or at least lead to a dialogue on the matter in question if States or other subjects of international law do not react negatively. At this point the work of the national judge is not different from that of an international judge.

Regarding the how, it is worth to underlining an issue. National judges can no longer function exclusively under the logic and methodology of national law, following old theoretical models. Many of the risks of this new scenario arise from the lack of awareness of the national judges of their role as agents of international law and what it implies as well as their lack of proper methodology. In other words, national judges must recognise that they are agents of international law and, in this sense, that it is not enough to know the criminal, labour and commercial law of their States; They must also be aware of international law and the logic with which it operates. Moreover, national judges cannot continue to operate under concepts as useless as incorporation, hierarchy or any other idea associated with the old zombies of dualism and monism. It is in their hands to generate some order amid chaos, to claim national interests without abandoning international commitments, to nuance the harmful effects of international norms and logics and, to help achieving the effectiveness of international law. ${ }^{95}$

In this respect, it is worth saying that the work of national judges cannot lead to the absolute ineffectiveness of international commitments. Nuances, exceptions, and conditions are allowed, however, never should never be accepted unjustified breaks. In order to achieve a balance, it is fundamental to seek a paradigm shift in the way relations between international law and domestic law are conceived as well as the renewal of national judges'

94 Ibid.

95 Nollkaemper has shown the way in which national judges have pushed some changes in international law when reacting to international rules that undermine some constitutional values. See: "Rethinking the supremacy of international law", supra nt 57. 
knowledge and methodology. However, above all, it is necessary for international law and its authorities to recognise the voice of national judges. Dismissing them saying that their work is just a fact from the perspective of international law will no longer work. International authorities, especially international courts, must engage in a fruitful dialogue with national judges. Perhaps this is the biggest challenge we have at hand. 